\title{
Smell and Taste Metaphors in J. Harris' and E. Bauermeister's Novels: a Functional Aspect
}

\author{
T. Sydorenko \\ Kyiv National Linguistic University \\ Corresponding author. E-mail: tomsol91@gmail.com
}

Paper received 28.10.17; Revised 03.11.17; Accepted for publication 05.11.17.

https://doi.org/10.31174/SEND-PH2017-145V41-13

\begin{abstract}
This article considers the issue of smell and taste sensory imagery in terms of its verbal representation in Chocolat and Blackberry Wine by the British writer Joanne Harris and in The School of Essential Ingredients by the American author Erica Bauermeister. The research focuses on the role and functions of olfactory and gustatory imagery in the novels, as well as their metaphoric expression. Smell and taste imagery is regarded in terms of personality identification, social situation and cognition, as well as a reflection of empirical, aesthetic, and psychological experience.
\end{abstract}

Keywords: smell, taste, sensory imagery, metaphoric expression, personality identification.

Introduction. Smell and taste have been of interest to scholars for quite a long time. They belong to the traditional five senses, first singled out in Aristotle's De Anima alongside with sight, hearing and touch. As it is stated in the introduction to Olfaction, Taste and Cognition, 'olfactory experience is difficult to define: from ineffable to unmentionable, it seems to remain in the limbo of cognition' [8, p. 2]. However, this experience can be and is reflected in fiction, using various stylistic means. Throughout the literary history, smells performed the descriptive, plot-moving and even plot-defining function. Taking into account the fact that most of what we perceive as taste is actually smell, we can state that gustatory images have similar functions. Therefore, it is impossible to underestimate the role of smell and taste imagery in the world of fiction.

Metaphors have traditionally been viewed only as expressive means, but after a number of works on cognitive linguistics $[6,7]$ it began to be considered as "a mind operation on concepts, as a way of conceptualization that allows to experience a particular sphere of reality" [1, p.82]. Abstract notions generally belong to target domain, whereas the source domain is typically concrete. In the novels under analysis, we single out a number of conceptual metaphors based on linguistic ones. In some cases, source and target domain can switch places.

Results of investigation and their discussion. The novel Chocolat is centred around the influence of chocolate on the life of Vianne Rocher, the owner of the chocolate shop, and the inhabitants of the town. But apart from images directly linked to chocolate, there is an abundance of sensory images that refer to people, places and even feelings. Blackberry Wine, on the other hand, tells the story of a writer, Jay Mackintosh, whose interaction with wine leads him to discovering and rediscovering himself. It should be mentioned here that a bottle of wine itself tells the story, and this choice of narrator is quite unusual. It reminds us of the writings of Postmodernist authors, who gave the word to characters that were previously considered insignificant. Thus, the reader gets more insight into the events that are described from the viewpoint of outside observer. The School of Ess sential Ingredients gives insight into the way Lillian, a chef in a restaurant, manages to transform her cooking school students' lives by means of influence of smells and tastes.

Smells in Chocolat are often intensified by means of enumeration (e.g, a scent of primary school, of secrets whispered, of poster paint and newsprint and half-forgotten friends [5, p. 67] and detachments (e.g. I could smell the grief on him, a sour tang like earth and mildew [5, p. 189]. These contribute to a multiple perception of the smell. Furthermore, multiple epithets used by the narrators express their way of thinking. Vianne is underthe influence of her memories and torn between the impulse of freedom and the desire to stay at one place for her daughter's sake. Her antagonist Reynaud is also overwhelmed by contrary feelings and emotions he is trying to suppress. The clustering of epithets in his speech reveals his inner conflict. Compare Reynaud's description of Vianne's chocolaterie: the place is transformed; the air perfumed with bewildering scents of ginger and spices. I tried not to look at the shelves of sweets: boxes, ribbons, bows in pastel colours, sugared almonds in gold-silverdrifts, sugared violets and chocolate rose leaves.[5, p.74] Olfactory images are not only direct but also imagistic (usually metaphorical) descriptions.When Vianne says that the smell is like daylight trapped for years until it has gone sour and rancid [5, p.17] or describes grief as such that has a sour tang, she implies something unpleasant, endowing a particular smell with negative connotations. Therefore, the conceptual metaphor SOUR IS BAD can be brought to mind. Other metaphors include:

A. LIFE IS COOKING - this metaphor is especially vivid in the novel The School of Essential Ingredients. Based on plot analysis, its very name has double meaning: school that gives knowledge both about the ingredients essential for cooking and about neces sary elements of life. In particular, love is linked to the process of cooking: the scent, tinged with vanilla, travelled across the room in soft, heavy waves, filling the space with whispers of other kitchens, other loves [3, p.54]. By contrasting the tastes of cake and frosting, the difference between marriage mates, who are students of the cooking school, is illustrated : it's subtle, the difference in texture between the cake and the frosting as they cross your tongue [ibid, p.55].

B. PEOPLE ARE INGREDIENTS - students of Lillian's cooking school from The School of Essential Ingredients from their teacher's viewpoint were elements that would become more complex and intriguing as they mixed with one another, but at the beginning...their essence was clear [ibid, p.9]. Using notions from the semantic field of cooking (elements, mixed, essence), Lillian meditates about changes in her students' personalities throughout the course. Later, she tells one of them: We're 
all just ingredients, Tom. What matters is the grace with which you cook the meal (ibid, p.85), comparing people to components of a meal that must be properly cooked, or be successful in life (the grace with which you cook the meal. Lillian explains a young man's indecisiveness to propose: we all know some bread just takes more time to rise [ibid, p.105], metaphorically conveying a person's maturity to bread rising. And through the simile we approach the food we will be preparing like the guest list for a dinner partyeach guest invited for its own personality [ibid, p.62] the metaphor PEOPLE ARE INGREDIENTS is transformed into INGREDIENTS ARE PEOPLE.

C. PEOPLE ARE SPICES - the process of self-discovery and interaction with others is compared to the influence of spices: at some moment...each one's eyes would widen with joy or tears or resolution -it always happened. The timing and the reason would be different for each... No two spices work the same [ibid, p.10]. The wife of one of the characters describes him in terms of spices: 'you're the oregano', she said simply [ibid, p.79], implying his special personality. Spices are also personified, for example, as a child, Lillian discovers the maturity of a spice's taste: Lillian knew...that the spice was more grown-up than she was [ibid, p.24].

D. PERSONALITY IS WINE - in Blackberry Wine a bottle of wine is the narrator and active participant in the events narrated. Its expression the uneducated palate finds in us a brashness, a garrulousness which belies the deeper feelings...some things are not meant to be bottled for too long [4, p.135] has a double meaning, because the word combination uneducated palate which denotes the process of tasting is combined with brashness, garrulousness, that describe the personality of Jay, one of the main characters. In this way, a person who cannot appreciate the taste of wine is also unable to understand him fully.

E. SMELL IS PROTECTION/WEAPON- Jay's friend Joe carried a sachet with dry herbs as an amulet, without describing it as something supernatural: just a mixture of herbs and roots, gathered under favourable planetary conditions [ibid, p.56]. Jay is skeptical about that at first, but later believes in the power of smells when, thanks to the sachet, he somehow goes unnoticed by local bullies. Even when Joe is facing eviction, smells remain his only weapon: [Joe] was wearing one of his red flannel sachets around his neck ... a similar charm adorned every tree, every bush [ibid, p.75]. In Chocolat, Vianne, the owner of the chocolate shop, uses the smell of chocolate as an emotional weapon against her antagonist, he describes it in the following way: the creamy smell of chocolate is maddening ... pulling the threads of my senses apart, reaching into my mind [5. p. 156], that conforms the statement about aggressiveness of smells that we often have to perceive against our will [2, pp. 326-327].

Conclusions. We have singled out three main functions of smell and taste imagery in the story. These are triggers of memories, a way of self-presentation and a way of relat-ing to and judging others. As for conceptual metaphors, they reveal the double nature of smells and tastes and their key role in the lives of characters and plot development. Olfactory and gustatory components can function both as source and target domains.

\section{REFERENCES}

1. Ткачик О.В. Концептуальна метафора як спосіб пізнання дійсності [Е. ресурс]/ О. В. Ткачик // Вісник Луганського національного університету імені Тараса Шевченка. Філологічні науки. - 2013. - № 14(1). - С. 81-87. - Режим доступу: http://nbuv.gov.ua/UJRN/vluf_2013_14(1)_17

2. Черниговская Т. В. Семиотика запахов: вербализация, синестезия, память / Т.В. Черниговская // Чеширская улыбка кота Шрёдингера: язык и сознание. - М.: Языки славянской культуры, 2013. - С. $326-330$.

3. Bauermeister E. The School of Essential Ingredients / Erica Bauermeister. - N. Y.: Berkley Books, 2010. - 261 p.

4. Harris J. Blackberry Wine / Joanne Harris. - N. Y.: Random House, 2007. - 334 p.

5. Harris J. Chocolat / Joanne Harris. - N. Y.: Random House, 2007. $-382 \mathrm{p}$.

6. Kövecses Z. Metaphor: A Practical Introduction / Zoltan Kövecses. - Oxford: Oxford University Press, 2002. - 285 p.

7. Lakoff G. Metaphors We Live By / G. Lakoff, M. Johnson. Chicago: University of Chicago Press, 1980. -242 p.

8. Olfaction, Taste and Cognition / [ed. C. Rouby, B. Schaal]. New York: Cambridge University Press, 2002. - 462 p.

\section{REFERENCES TRANSLATED}

1. Tkachyk O.V. Conceptual Metaphor as a Means of World Cognition (an e-source) / O.V. Tkachyk // Lugansk National University named after T.Shevchenko Journal. Philological Sciences. - 2013. $\begin{array}{lllllll}- & N o & 14(1) . & - & P & 81- & 87 .\end{array}$ http://nbuv.gov.ua/UJRN/vluf_2013_14(1)_17

2. Chernigovskay a T. V. Semiotics of Smells: Verbalization, Synesthesia, Memory / T.V. Chernigovskay a // Cheshire Smile of Schroedinger's Cat: Language and Consciousness. - M.: Language and reasoning? 2013. - P. $326-330$.

\section{Метафоры запаха и вкуса в романах Дж. Харрис и Э. Бауэрмайстер: функциональный аспект Т. В. Сидоренко}

Аннотация. В статье рассматривается сенсорная образность запаха и вкуса в ее вербальной репрезентации в романах «Шоколад» и «Ежевичное вино» британской писательницы Джоан Харрис и «Школа основных ингредиентов» американской писательницы Эрики Бауэрмайстер. Целью исследования являются роль и функции ольфакторной и густаторной образности в романах, а также их метафорическая выраженность. Образность запаха и вкуса анализируется с позиций идентификации личности, социальной ситуации и познания, а также отражения эмпирического, эстетического и психологического опыта.

Ключевые слова: запах, вкус, сенсорная образность, метафорическая выраженность, идентификация личности. 